\title{
A NOVEL ROUTE FOR SYNTHESIS OF CORYPALLINE
}

\section{ANITA A. PANDEY ${ }^{1}$}

\author{
Department of Chemistry, D.S. (P.G.) College, Aligarh, U.P., India
}

\begin{abstract}
The present work describes a novel synthetic route for corypalline, using chloro methyl-methyl ether for cyclisation of $\mathrm{N}$-benzoyl derivative of substituted $\beta$-phenethylamine followed by hydrolysis and $\mathrm{N}$-methylation.

KEYWORDS: Corypalline, Chloromethyl-methyl Ether, cyclisation, N-methylation

The tetrahydroisoquinoline alkaloid Corypalline was isolated from Corydalis Pallida and Corydalis aurea by Manske. The structure (8) for this base was assigned on the basis of chemical and spectral evidences and further supported by its synthesis (MacLean and Snieckus, 1998). Bobbit et al. (1967) prepared corypalline (8) by the Pomeranz-Fritsch reaction of substituted $\mathrm{N}$ benzylaminoacetaldehyde diethyl acetal. Brossi et al., (1970) reported the synthesis of corypalline by partial demethylation of 3,4-dihydroisoquinoline derivative by treatment with conc. $\mathrm{HBr}$ followed by catalytic reduction of the imine methiodide intermediate. synthesized corypalline by a Pictet Spengler reaction of $\beta$-(4benzyloxy-3-methoxy) phenethyl amine. Synthesized corypalline starting with the 3-isochromanone intermediate.

The present work describes a novel synthetic route for Corypalline using chloromethyl-methyl ether for cyclisation of N-benzoyl devirative of substituted $\beta$ phenethyl amine followed by hydrolysis and $\mathrm{N}$ methylation.

Vanillin (1) on benzylation with benzyl chloride gave the O-benzyl vanillin (2) which on treatment with nitromethane gave 4-benzyloxy-3-methoxy- $\omega$-nitro styrene (3). Lithium aluminium hydride reduction of substituted $\omega$-nitrostyrene gave corresponding $\beta$ phenethylamine (4) which on benzoylation with benzoyl chloride gave N-benzoyl derivative (5). This (5) was treated with chloromethylmethyl ether to give N-benzoyl1,2,3,4-tetrahydroisoquinoline derivative (6) which on hydrolysis followed by $\mathrm{N}$-methylation and debenzylation gave Corypalline (8).
\end{abstract}<smiles>CCOc1ccc(C=O)cc1OCC(C)(C)C(=O)Oc1ccc(/C=C\[N+](=O)[O-])cc1OC</smiles>

(1)

(2)

(3)<smiles>CCC(C)C(C)CC</smiles><smiles>COc1cc(CCNC(=O)c2ccccc2)ccc1OC(C)(C)C(=O)O</smiles>

(5)<smiles>COc1cc(CCN)ccc1OC(C)(C)C</smiles>

(4)<smiles>COc1cc2c(cc1OC(C)(C)C)CN(C(=O)c1ccccc1)CC2</smiles>

(6)<smiles>COc1cc2c(cc1OC(C)(C)C)CNCC2</smiles>

(7)<smiles>COc1cc2c(cc1O)CN(C)CC2</smiles>

(8)

Corypalline

${ }^{1}$ Corresponding author 


\section{EXPERIMENTAL}

(I) Synthesis of O-benzyl vanillin: (2)-A mixture of vanillin(1) (7.6 g), anh. potassium carbonate $(5.0 \mathrm{~g})$, benzyl chloride $(4 \mathrm{~mL})$, sodium iodide $(0.4 \mathrm{~g})$ and ethanol $(130 \mathrm{~mL})$ was stirred and refluxed for $6 \mathrm{~h}$. After cooling, the solvent was distilled out in vacuo and resulting oil poured into alkaline ice cold water $(250 \mathrm{~mL})$. The solid product was crushed under water, filtered and dried $\left(\mathrm{Na}_{2} \mathrm{SO}_{4}\right)$. Recrystallisation from aq. ethanol gave Obenzyl vanillin (2).(9.6 g; 79.34\%), m.p. $64-65^{\circ} \mathrm{C}$.

(Found C,74.2, H,5.96, O-19.8, $\mathrm{C}_{15} \mathrm{H}_{14} \mathrm{O}_{3}$ requires C 74.5; H 5.78; O 19.9\%)

(II) Synthesis of 4-benzyloxy-3-methoxy- $\omega$-nitrostyrene: (3)- A mixture of O-benzylvanillin (2) (9 g), ammonium acetate $(3 \mathrm{~g})$, nitromethane $(15 \mathrm{~mL})$ and glacial acetic acid $(25 \mathrm{~mL})$ was refluxed for $1.5 \mathrm{~h}$. The crystals of the product which deposited on cooling were filtered, dried and recrystallised from ethanol to give the styrene (3) as yellow needles $(8.47 \mathrm{~g} ; 80 \%)$ m.p. $120-122^{0} \mathrm{C}$ (lit ${ }^{6}$,m.p. $\left.121-123^{0} \mathrm{C}\right)$.

(Found C:67.42; H: 5.25; N:4.90; $\mathrm{C}_{16} \mathrm{H}_{15} \mathrm{NO}_{4}$ requires C:67.36; H:5.26; N:4.91\%)

(III) Synthesis of 4-benzyloxy-3-methoxy- $\beta$ phenethylamine: (4)- To a stirred suspension of lithium aluminium hydride (5.36 g) in tetrahydrofuran was added the styrene (3) $(8 \mathrm{~g})$, in portions, with ice bath cooling. The mixture was refluxed at $100^{\circ} \mathrm{C}$ for $4 \mathrm{~h}$, cooled, excess hydride was decomposed by addition of water and mixture was extracted with methylene dichloride. The extract was washed with $2 \mathrm{~N}$ aq. sodium hydroxide, washed with water, dried $\left(\mathrm{Na}_{2} \mathrm{SO}_{4}\right)$ and solvent removed to give the amine as oil $(5.62 \mathrm{~g}, 78 \%)$. The hydrochloride had m.p. $171-172^{\circ} \mathrm{C}$.

(IV) Synthesis of N-benzoyl-2-(4'-benzyloxy-3'-methoxy phenyl) ethyl amine:(5)-To a stirred mixture of 2-(4benzyloxy-3'-methoxy phenyl) ethyl amine (5.5 g) in benzene $(45 \mathrm{~mL})$ and $4 \mathrm{~N} \mathrm{NaOH}(90 \mathrm{~mL})$ was added about $11 \mathrm{~mL}$ of benzoyl chloride in small portions of $0.5 \mathrm{~mL}$ each with cooling in water. The stirring was continued for $2.5 \mathrm{~h}$ at room temperature. The benzene layer was then separated, washed with $1 \mathrm{~N} \mathrm{HCl}$, water, dried $\left(\mathrm{Na}_{2} \mathrm{SO}_{4}\right)$ and the solvent removed under reduced pressure to give (5) $(5.8 \mathrm{~g} ; 75 \%)$ m.p. $133^{\circ} \mathrm{C}$.

IR(KBr):3320 cm$-1(\mathrm{NH}): 1630 \mathrm{~cm}^{-1}(\mathrm{C}=\mathrm{O})$.

(Found C:76.72; $\mathrm{H}: 6.21 ; \mathrm{N}: 3.59 ; \mathrm{C}_{23} \mathrm{H}_{23} \mathrm{NO}_{3}$ requires C:76.45; H:6.37; N:3.88\%)
(V) Preparation of monochloromethyl ether: In a round bottomed flask fitted with a stopper carrying a reflux condenser and a glass tube reaching nearly to the bottom of the flask were placed $35 \mathrm{~g}$ (1.09 mole) of methyl alcohol and $90 \mathrm{~g}$ of technical formalin containing $25.2 \mathrm{~g}$ (0.84 mole) of formaldehyde.

A rapid stream of hydrogen chloride was run in to the mixture which was cooled with running water. In about $1.5 \mathrm{~h}$ a layer of monochloromethyl ether started appearing. The stream of hydrogen chloride was continued for $0.5 \mathrm{~h}$ longer until the solution was saturated. The layer of monochloromethyl ether was then seperated. The water layer was saturated with $\mathrm{CaCl}_{2}$ and more ether separated. This was added to the main portion which was then dried over $\mathrm{CaCl}_{2}$ and fractionally distilled (b.p. $56^{\circ} \mathrm{C}$ )

(VI) Synthesis of N-benzoyl-7-benzyloxy-6 methoxy1,2,3,4-tetrahydro isoquinoline:(6)-A mixture of monochloromethyl ether ( $3 \mathrm{~g}$ ) in glacial acetic acid $(25 \mathrm{~mL})$ was treated with N-benzoyl-2-(4'-benzyloxy-3'methoxyphenyl) ethyl amine $(5.5 \mathrm{~g})$ at about $18^{0} \mathrm{c}$ for eighteen hour. The excess solvent and reagent were removed under reduced pressure. The residue was washed with $25 \% \quad \mathrm{NH}_{3}$ solution, extracted with ethyl acetate, washed with water, dried $\left(\mathrm{Na}_{2} \mathrm{SO}_{4}\right)$ and the solvent removed to afford (6)(4.08 g; 72\%) m.p. $108^{\circ} \mathrm{C}(\mathrm{MeOH}-$ ether)

IR(KBr): $1650 \mathrm{~cm}^{-1}(\mathrm{C}=\mathrm{O})$

(Found C: 76.92; $\mathrm{H}: 6.18 ; \mathrm{N}: 3.72 ; \mathrm{C}_{24} \mathrm{H}_{23} \mathrm{NO}_{3}$ requires $\mathrm{C}$ : 72.21; H: 6.16; N: $3.75 \%$ )

(VII)Synthesis of 7-benzyloxy-6-methoxy-1,2,3,4tetrahydroisoquinoline:(7)-N-benzoyl-7-benzyloxy-6methoxy-1,2,3,4-tetrahydroisoquinoline (6) ( $4.0 \mathrm{~g}$ ) was refluxed with $30 \%$ methanolic $\mathrm{KOH} \quad(60 \mathrm{~mL})$ for thirty minute, cooled and was made acidic with the addition of conc. $\mathrm{HCl}$ drop by drop. The acid separated was filtered off and the filtrate was then made alkaline with $\mathrm{NaOH}$ solution, cooled and extracted with ether. After extraction, the ether was evaporated under reduced pressure to give $(7)(2.30 \mathrm{~g} ; 80 \%)$ m.p. $130^{\circ} \mathrm{C}$.

$\operatorname{IR}\left(\mathrm{CHCl}_{3}\right): 3269 \mathrm{~cm}^{-1}(\mathrm{NH})$

(Found C:75.48, H: 6.92; N: 5.00; $\mathrm{C}_{17} \mathrm{H}_{19} \mathrm{O}_{2} \mathrm{~N}$ requires C:75.81; H: 7.11; N: 5.20\%)

The hydrochloride salt recrystallised from methyl alcohol-ether gave colourless scales m.p. $218^{0} \mathrm{C}$.

(VIII) Synthesis of 7-hydroxy-6-methoxy-2-methyl1,2,3,4-terahydro isoquinoline: (8)- 
To a solution of 7-benzyloxy-6-methoxy1,2,3,4-tetrahydroisoquinoline (7) $(2.0 \mathrm{~g})$ in $180 \mathrm{~mL}$ of methyl alcohol, was added $37 \%$ formaline $(4.5 \mathrm{~mL})$ and the reaction mixture was stirred for 45 minutes. To this was added sodium borohydride $(21 \mathrm{~g})$ within $15 \mathrm{~min}$. The stirring was continued for $45 \mathrm{~min}$. and then the mixture was acidified with $10 \% \mathrm{HCl}$ solution. After removal of solvent in vacuo, the residue left was basified with ammonia and extracted with benzene, dried over $\mathrm{Na}_{2} \mathrm{SO}_{4}$ and evaporated. The solid left was taken in ethanol (50 $\mathrm{mL})$ and $12 \mathrm{~N} \mathrm{HCl}(50 \mathrm{~mL})$ mixture and refluxed for $3 \mathrm{~h}$. Neutralisation with aq. $\mathrm{NaOH}$ and extraction with chloroform, followed by distillation off the solvent in vacuo left a residue which was recrystallised from benzene to give corypalline $(8)(1 \mathrm{~g} ; 70 \%)$ m.p. $166^{\circ} \mathrm{C}$ $\left(\mathrm{lit}^{1} ; 164-165^{0} \mathrm{C}\right)$

NMR $\left(\mathrm{CDCl}_{3}+\mathrm{DMSO}_{6}\right): 2.36(3 \mathrm{H}, \mathrm{N}-\mathrm{Me}), 2.51-2.84$ $\left(4 \mathrm{H}, \mathrm{m},-\mathrm{CH}_{2}-\mathrm{CH}_{2}\right), 3.40\left(2 \mathrm{H}, \mathrm{s}, \mathrm{C}_{1}-\mathrm{H}\right) 3.0(3 \mathrm{H}, \mathrm{s}, \mathrm{OMe})$, $4.37\left(1 \mathrm{H}\right.$, broad signal,-OH, exchangeable with $\left.\mathrm{D}_{2} \mathrm{O}\right)$, $6.53\left(1 \mathrm{H}, \mathrm{s}, \mathrm{C}_{8}-\mathrm{H}\right), 6.66\left(1 \mathrm{H}, \mathrm{s}, \mathrm{C}_{5}-\mathrm{H}\right) \mathrm{ppm}$

MS m/e:193 $\left(\mathrm{M}^{+}\right)$, 177, 150 and 135

Found C:68.38, H: 7.90; N: 7.80; $\mathrm{C}_{11} \mathrm{H}_{15} \mathrm{NO}_{2}$ requires C: 69.56; H:7.77; N: 7.25\%)

\section{ACKNOWLEDGEMENT}

Author is extremely thankful to Professor K. P. Tiwari, Department of Chemistry, University of Allahabad, for his valuable guidance.

\section{REFERENCES}

MacLean D.B. and Snieckus V., 1998. R.H.F. Manske: Fifty Years of Alkaloid Chemistry. The Alkaloid Chemistry and Biology, 50: 3-59.

Bobbit J.M., Roy D.N., Marchand A. and Allen C.W., 1967. Synthesis of Isoquinoline VI N-alkyl 1,2,4-Tetrahydroisoquinoline. J. Org. Chem., 32: 2225 .

Brossi A., O'Brian J. and Teital S., 1970. Organic Preparation and Procedures, 2: 281.

Whaley and Govindachari T.R., 2004. The PictetSpangler, Synthesis of Tetrahydroisoquinoline and Related Compounds. Organic. Reactions.

Finkelstein J.J., 1951. The Synthesis of dl coclaurine. Amer. Chem. Soc., 73: 550.

Lange N.A. and Humbourger W.E., 1931. Condensation of aromatic aldehydes with nitromethane. J. Amer. Chem. Soc., 53:3865. 